\title{
Obraz Żydówek na froncie wschodnim II wojny światowej we współczesnych rosyjskojęzycznych mediach żydowskich. Na przykładzie wydania internetowego amerykańskiego czasopisma „Jewriejskij Mir”
}

\section{THE IMAGE OF JEWISH WOMEN ON THE EASTERN FRONT OF WORLD WAR II IN CONTEMPORARY RUSSIAN-LANGUAGE JEWISH MEDIA: THE EXAMPLE OF THE ONLINE EDITION OF THE AMERICAN NEWSPAPER YEVREISKI MIR}

\begin{abstract}
The main aim of this paper is to present the image of Jewish women participating in hostilities on the Eastern Front of World War II in the contemporary Russian-language Jewish media on the example of the online edition of the American newspaper Yevreiski Mir. An analysis of its articles proves that the fates of women of Jewish origin in the Red Army and the Soviet resistance movement are used by the authors to strengthen social ties among Russian-speaking Jews. Moreover, it is shown that the use of biographical threads of selected Jewish women helps journalists create a new narrative in which Jewish women are presented not only as victims but also as war heroines proud of their origin.
\end{abstract}

Keywords: Jewish women, World War II, media, Yevreiski Mir, Soviet Jews.

Słowa kluczowe: Żydówki, II wojna światowa, media, „Jewriejskij Mir”, Żydzi sowieccy. 


\section{Wprowadzenie}

Szacuje się, że na froncie wschodnim II wojny światowej w Armii Czerwonej służyć mogło - według różnych obliczeń - od ok. 300 tys. do nawet ponad 500 tys. osób pochodzenia żydowskiego ${ }^{1}$. Wśród nich znajdowało się przypuszczalnie ok. 20 tys. Żydówek². Ogółem jednak liczba kobiet żydowskich biorących udział w walce $\mathrm{z}$ niemieckim najeźdźcą na terenach okupowanego Związku Socjalistycznych Republik Sowieckich (dalej: ZSRS) staje się większa, gdy w wyliczeniach uwzględni się również osoby związane z ruchem oporu ${ }^{3}$. Niezależnie jednak od przyjętych danych liczbowych należy stwierdzić, iż funkcje, jakie te kobiety spełniały w okresie walk z okupantem, były nie tylko niezwykle istotne, lecz także różnorodne. Brały one bowiem udział w działaniach wojennych, zarówno angażując się w bezpośrednią walkę z przeciwnikiem, jak i opiekując się rannymi czy też pracując jako łączniczki. W związku z tym powojenna historiografia, ale też i środowiska rosyjskojęzycznych Żydów stanęły przed podwójnym dylematem.

$\mathrm{Z}$ jednej strony musiały one ustosunkować się do roli, jaką odegrali Żydzi sowieccy jako grupa w walce z nazizmem. W historiografii sowieckiej kwestia ta była marginalizowana lub wręcz pomijana ${ }^{4}$, a wszelkie próby podkreślania u bojowników żydowskich poczucia tożsamości narodowej bądź też grupowego solidaryzmu były traktowane jako przejawy „kosmopolityzmu" i niebezpiecznych tendencji nacjonalistycznych. $\mathrm{Z}$ tego też względu pierwsze rzetelne badania nad udziałem Żydów w walce na froncie wschodnim II wojny światowej zapoczątkowane zostały poza

${ }^{1}$ Zob. np. Mordechai Altshuler, Jewish Combatants of the Red Army Confront the Holocaust, [w:] Soviet Jews in World War II: Fighting, Witnessing, Remembering, red. Harriet Murav, Gennady Estraikh, Boston 2014, s. 16. Inne szacunki podaje m.in. Jicchak Arad, który w swojej książce oszacował liczbę Żydów walczących w Armii Czerwonej na ok. 490-520 tys. - zob. Yitzhak Arad, In the Shadow of the Red Banner: Soviet Jews in the War Against Nazi Germany, Jerusalem 2010, s. 5. Natomiast według danych opublikowanych przez Centralne Archiwum Ministerstwa Obrony Federacji Rosyjskiej - w Armii Czerwonej mogło służyć 501 tys. żołnierzy żydowskiego pochodzenia, zob. np. Aron Szniejer (Shneyer), Plen: Sowietskije wojennoplennyje w Giermanii 1941-1945, Moskwa-Ijerusalim 2005, w: Jewniverse - Yiddish Shteytl, http://www.jewniverse.ru/RED/Shneyer/index.htm [dostęp: 11 kwietnia 2021].

2 Tamże.

${ }^{3}$ Ogółem liczba osób pochodzenia żydowskiego walczących w oddziałach partyzanckich oscyluje pomiędzy 20 a 30 tys. - zob. Reuben Ainsztein, Jewish Resistance in Nazi-Occupied Eastern Europe: With a Historical Survey of the Jew as Fighter and Soldier in the Diaspora, New York 1974, s. 394-395.

${ }^{4}$ Por. np. Piotr Pospiełow, Istorija Wielikoj Otieczestwiennoj Wojny Sowietskogo Sojuza 1941-1945 gg., t. 1-6, Moskwa 1960-1965. 
blokiem wschodnim, czego wyrazem stały się prace m.in.: Hersza Smolara ${ }^{5}$, Dova Levina, Jicchaka Arada i Mordechaia Altshulera, a obecnie Zviego Gitelmana czy też - w przypadku pozycji rosyjskojęzycznych - np. Olega Budnickiego $^{6}$. Co ważne, badacze ci uwzględniali również zaangażowanie kobiet w działania wojenne. Niemniej jednak dopiero w ostatnich latach zaczęły się pojawiać odrębne prace dotyczące walczących Żydówek sowieckich, traktujące ich płeć jako osobną kategorię analizy historycznej. W szczególności istotne są dwie pozycje: Radzieckie kobiety w walce z 2010 r. ${ }^{7}$ autorstwa Anny Krylovej oraz Soviet Women on the Frontline in the Second World War Rogera D. Markwicka i Euridice C. Cardony ${ }^{8}$, która wydana została w $2012 \mathrm{r}$.

Wszystkie wspomniane wyżej prace, jak i inne publikacje poświęcone udziałowi sowieckich kobiet żydowskich w działaniach na froncie wschodnim wniosły istotny wkład w proces utrwalania pamięci o ich poświęceniu. Jednakże rezultaty badań historyków nie zawsze w sposób znaczący wpływają na narrację historyczną dziennikarzy. Uwaga ta jest o tyle istotna, iż to właśnie ci drudzy za pomocą środków masowego przekazu mają większy wpływ na kształtowanie świadomości historycznej społeczeństwa.

W niniejszym artykule podjęta zostanie próba odpowiedzi na pytanie, w jaki sposób pamięć o Żydówkach uczestniczących w działaniach bojowych II wojny światowej kształtowana jest we współczesnych rosyjskojęzycznych mediach żydowskich. Przedmiotem analizy są artykuły zamieszczone w ukazującym się od 2003 r. wydaniu internetowym amerykańskiego tygodnika „Jewriejskij Mir” (Yevreiski Mir). Wybór ten podyktowany został stale rosnącą popularnością tegoż czasopisma wśród posługujących się językiem rosyjskim Żydów9. Na podstawie badań statystycznych możliwe jest określenie odsetka materiałów poświęconych wkładowi kobiet żydowskich $\mathrm{w}$ walkę z niemieckim okupantem oraz porównanie z odpowiednimi

${ }^{5}$ Dużą wartością publikacji Smolara, dotyczących w szczególności zaangażowania Żydów sowieckich w działalność ruchu oporu na terenie okupowanej Białorusi, a także w mińskim getcie, jest fakt, iż w dużej mierze opierają się one na osobistych przeżyciach autora i jego późniejszej działalności w sowieckich oddziałach partyzanckich. Por. Hersh Smolar, The Minsk Ghetto: Soviet-Jewish Partisans Against the Nazis, New York 1989.

${ }^{6}$ Zob. np. Oleg Budnicki, Mużcziny i żenszcziny w Krasnoj Armii (1941-1945), „Cahiers du Monde Russe" 52 (2011), nr 2-3, s. 405-422.

${ }^{7}$ Polskie wydanie: Anna Krylova, Radzieckie kobiety w walce. Historia przemocy na froncie wschodnim, tłum. Kamil Janicki, Zakrzewo 2012.

${ }^{8}$ Roger D. Markwick, Euridice C. Cardona, Soviet Women on the Frontline in the Second World War, New York 2012.

${ }_{9}$ Według danych z 13 kwietnia 2021 r. czasopismo to jedynie na portalu Facebook miało 3578 obserwujących. 
danymi dla innych publikacji dotyczących działalności Żydów sowieckich na froncie wschodnim. Natomiast analiza treści artykułów pozwala na wyodrębnienie i ukazanie najważniejszych - z punktu widzenia dziennikarzy - przykładów kobiecych postaw i sylwetek. Kwestia ta jest o wiele lepiej prezentowana w odniesieniu do udziału Żydówek w Armii Czerwonej niż do ich uczestnictwa w partyzantce.

\section{Statystyki}

Udzielenie odpowiedzi na powyższe pytania nie będzie możliwe, jeśli wcześniej nie zwróci się uwagi na specyfikę środowiska, z którego wywodzą się zarówno twórcy przekazu, jak i jego odbiorcy. W przypadku czasopisma „Jewriejskij Mir” jest to społeczność dawnych Żydów sowieckich oraz ich potomków. Z danych przedstawionych przez Marka Toltsa wynika, że tylko w latach 1989-2009 z ZSRS oraz jego dawnych terenów wyemigrowało ok. 326 tys. Żydów. Jeśli jednak uwzględniłoby się w obliczeniach także wcześniejsze fale emigracyjne $\mathrm{z}$ lat siedemdziesiątych i osiemdziesiątych XX w., to łączna liczba emigrantów żydowskich z obszarów dawnego państwa sowieckiego wyniosłaby w Stanach Zjednoczonych prawie 500 tys. ${ }^{10}$ Ludność ta w wyniku polityki władz komunistycznych w znacznej części utraciła swoją tożsamość żydowską, dlatego też podstawowym celem amerykańskiej społeczności rosyjskojęzycznych Żydów stało się przede wszystkim jej odzyskanie. Dotyczyło to zarówno sfery religijnej, jak i narodowej oraz kulturowej. Jednym z rezultatów tych działań było właśnie powstanie mediów żydowskich w języku rosyjskim, w tym właśnie tygodnika „Jewriejskij Mir”, który po raz pierwszy ukazał się w wersji papierowej w 1992 r. w Nowym Jorku. Jego założycielem oraz redaktorem naczelnym został rabin Arje (Lew) Kacyn.

Choć strona wydania internetowego czasopisma wskazuje, iż jest ono „forum dyskusji na palące tematy związane z polityką, kulturą i religią"11, to jednak istotną rolę w jego przekazie odgrywa też historia. Dla czytelników stanowi to okazję do bliższego poznania zagadnień związanych z dziejami Żydów, państwa sowieckiego czy też Stanów Zjednoczonych.

${ }^{10}$ Mark Tolts, Demography of the Contemporary Russian-Speaking Jewish Diaspora, [w:] The New Jewish Diaspora: Russian-Speaking Immigrants in the United States, Israel, and Germany, red. Zvi Gitelman, New Brunswick 2016, s. 24.

${ }_{11}$ Zob. O nas, „Jewriejskij Mir” (b.d.), https://evreimir.com/o-nas/ [dostęp: 11 kwietnia 2021]. 
Jednakże z punktu widzenia niniejszych rozważań o wiele istotniejsza jest inna funkcja tekstów o charakterze historycznym w tymże czasopiśmie, mianowicie ukazywanie cierpienia oraz bohaterstwa Żydów sowieckich w okresie II wojny światowej, a także podczas istnienia samego ZSRS. W taką narrację mogą się więc wpisywać materiały poświęcone takim kwestiom, jak np. terror okresu stalinizmu, Holokaust, ale też i właśnie zaangażowanie ludności pochodzenia żydowskiego w walkę z okupantem. Przeprowadzona analiza treści artykułów wydania internetowego czasopisma „Jewriejskij Mir” z lat 2003-2020 wykazała, iż w badanym okresie ukazało się łącznie 131 publikacji związanych z kwestią udziału Żydów w walkach z hitlerowskim okupantem na froncie wschodnim (wykres 1).

Jak można zauważyć na wykresie 1, istnieje wyraźna dysproporcja między liczbą artykułów zawierających wzmianki o zaangażowaniu Żydówek w działania wojenne na terenie ZSRS i na froncie wschodnim a liczbą pozostałych artykułów, w których podejmowano problem udziału Żydów w walkach niemiecko-sowieckich. Tych pierwszych ukazało się do końca roku 2020 łącznie 25, co stanowiło niewiele ponad 19\% publikacji na temat działań wojennych na Wschodzie z lat 1941-1945, które w historiografii sowieckiej, a później też rosyjskiej, określa się mianem wielkiej wojny ojczyźnianej. Udział pozostałych artykułów wyniósł prawie 81\%, co - przekładając na liczby - stanowiło 106 materiałów dziennikarskich. Różnica ta może potencjalnie wprowadzać w błąd i sugerować pozorną marginalizację roli Żydówek w odniesieniu zwycięstwa nad nazizmem. Należy jednak zauważyć, iż kobiety żydowskie stanowiły w samej tylko Armii Czerwonej - w zależności od przyjętych liczb - od 4 do nawet ok. $6,7 \%$ ogólnej liczby osób pochodzenia żydowskiego. W świetle niniejszych danych można więc mówić nawet o swoistej nadreprezentacji kobiet w badanych artykułach. $Z$ tego też względu trzeba stwierdzić, iż pomimo wyraźnych związków z konserwatyzmem oraz judaizmem, m.in. poprzez osobę redaktora naczelnego i innych publicystów związanych ze sferą religijną, redakcja czasopisma nie marginalizuje pamięci o wojennych zasługach Żydówek sowieckich. Wręcz przeciwnie, usilnie dąży do wzmocnienia w czytelnikach poczucia żydowskiego solidaryzmu grupowego, ukazując zwycięstwo nad III Rzeszą jako rezultat ofiary poniesionej przez cały naród żydowski - niezależnie od płci, wykształcenia czy pochodzenia społecznego.

Analizując badane publikacje, zauważyć można jednak inny problem, który zilustrowany jest na wykresie 2. 


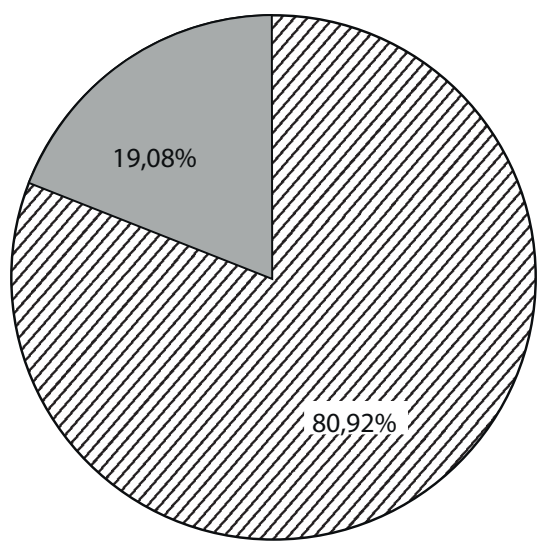

Artykuły wspominające o zaangażowaniu Żydówek w walki na froncie wschodnim II wojny światowej

$\bigotimes$ Artykuły na temat zmagań na froncie wschodnim, w których nie wspomniano o udziale Żydówek w walkach

Wykres 1. Artykuły wydania internetowego czasopisma „Jewriejskij Mir” wspominające o udziale sowieckich Żydówek w walkach na froncie wschodnim II wojny światowej na tle pozostałych publikacji dotyczących udziału Żydów z ZSRS w działaniach wojennych w przeliczeniu na procenty $(n=131)$

Źródło: badania własne na podstawie artykułów zamieszczonych na stronie internetowej czasopisma $\mathrm{z}$ lat 2003-2020.

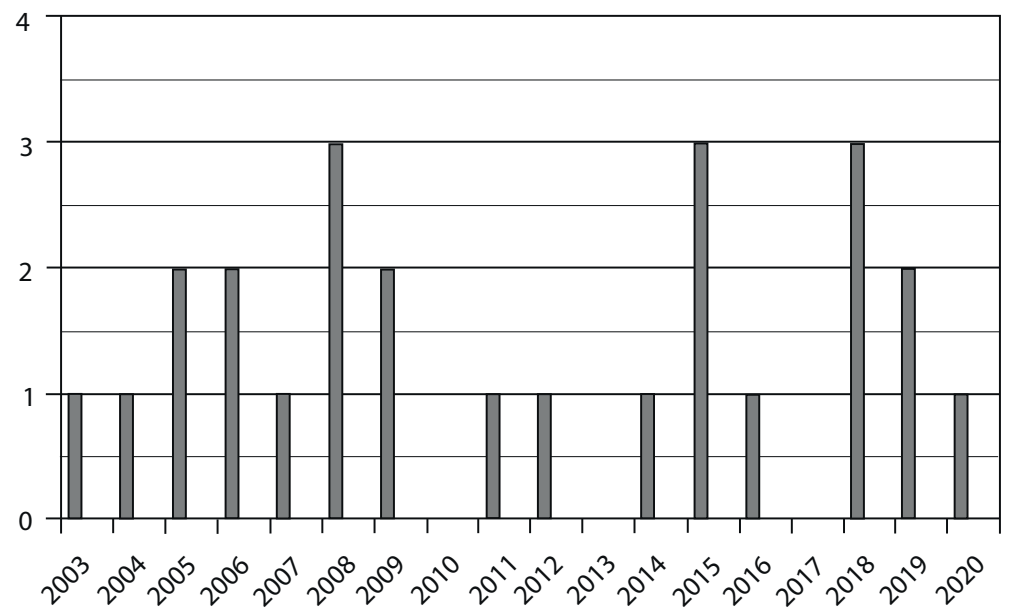

Wykres 2. Liczba artykułów w wydaniu internetowym czasopisma „Jewriejskij Mir” w latach 2003-2020 wspominających o udziale Żydówek sowieckich w walkach na froncie wschodnim II wojny światowej

Źródło: badania własne na podstawie artykułów zamieszczonych na stronie internetowej czasopisma z lat 2003-2020. 
W początkowym okresie istnienia wydania internetowego czasopisma, tj. w latach 2003-2009, wzmianki o Żydówkach walczących na froncie wschodnim II wojny światowej nie pojawiały się co prawda często, ale były stosunkowo regularne. Każdego roku wspominano o ich poświęceniu przynajmniej raz. Później jednak częstotliwość takich publikacji zmalała. W latach 2010, 2013 i 2017 nie został opublikowany ani jeden artykuł o charakterze historycznym, w którym pojawiłyby się jakiekolwiek odniesienia do wojennych zasług Żydówek sowieckich. Z drugiej jednak strony to właśnie po roku 2009, a dokładniej - w 2015 i 2018, ukazało się najwięcej takich wzmianek w ciągu roku: we wspomnianych latach odnotować można po trzy publikacje związane z kwestią kobiet żydowskich walczących z niemieckim okupantem na terenach ZSRS. Wydaje się, że przytoczone tu rezultaty badawcze wyjaśnić można co najmniej kilkoma czynnikami. Regularność ukazywania się podobnych publikacji w latach 2003-2009 wynikała zapewne z faktu, iż rosyjskojęzyczna społeczność żydowska w Stanach Zjednoczonych, a szczególnie ludność, która przybyła tam po rozpadzie państwa sowieckiego w 1991 r., w dalszym ciągu jeszcze wówczas odkrywała swoją żydowską tożsamość oraz przeszłość swojej wspólnoty. Relatywnie częste przypominanie przez redakcję czasopisma „Jewriejskij Mir” we wspomnianym okresie o wojennych zasługach Żydów sowieckich, w tym również kobiet, służyło wzmacnianiu więzi społecznych grupy, a także było pomocne w procesie asymilacji emigrantów. Gdy rezultaty tychże działań stały się widoczne, publicyści mogli po prostu uznać, iż po zasygnalizowaniu czytelnikom problemu udziału żydowskich obywateli ZSRS w zmaganiach II wojny światowej konieczne jest rozwinięcie w wydaniu internetowym czasopisma innych wątków historycznych, np. Holokaustu ${ }^{12}$. Ponadto nagłe zmniejszenie w latach 2010-2014 liczby wzmianek o walczących Żydówkach mogło być spowodowane czynnikiem biologicznym, czyli wymieraniem kolejnych świadków historii, w tym przypadku weteranów wojennych ${ }^{13}$.

${ }^{12}$ O kwestii Holokaustu w narracji tygodnika „Jewriejskij Mir” zob. Wieronika Mużykowska, Walerij Amirow, Tragiedija Chołokosta i zarubieżnyje russkojazycznyje jewriejskije SMI: osobiennosti sowriemiennogo osmyslenija, „Politiczeskaja Lingwistika” (2018), nr 1, s. 82-86. Podstawą badań autorów były jednak papierowe wydania gazety z lat 2015-2017. Tylko w tym okresie - zgodnie z ich obliczeniami - ukazały się na łamach czasopisma 83 materiały poświęcone tematyce Holokaustu.

${ }^{13}$ Za przykład może tutaj posłużyć zmarły w 2005 r. Anatolij Szapiro - weteran Armii Czerwonej, który 27 stycznia 1945 r. pierwszy otworzył bramę obozu Auschwitz-Birkenau. Jego wspomnienia często inspirowały publicystów czasopisma. Zob. np. Oni byli pierwymi, „Jewriejskij Mir” (9 marca 2005), https://evreimir.com/5845/ [dostęp: 12 kwietnia 2021]. 
Ciekawym zjawiskiem jest również cykliczny wzrost liczby podobnych publikacji w określonych latach. Poza wspomnianymi już latami 2015 i 2018 zauważalne jest to także wcześniej: w roku 2008 o sowieckich kobietach żydowskich na froncie wzmiankowano trzykrotnie. W praktyce świadczyć to może o osiągnięciu przez społeczność rosyjskojęzycznych Żydów w Stanach Zjednoczonych swoistej „dojrzałości” w sferze pamięci i świadomości historycznej. Wraz bowiem z upływem kolejnych lat przypominanie wojennych dokonań Żydówek sowieckich i ich sylwetek w wydaniu internetowym czasopisma przestawało być spontaniczną „opowieścią” o przeszłości. Zamiast tego konkretne historie i wzmianki zostały przyporządkowane odpowiednim rocznicom, dzięki czemu stały się ich częścią. Dlatego też w latach 2008 i 2018, kiedy to przypadały kolejno sześćdziesiąta piąta i siedemdziesiąta piąta rocznica likwidacji getta w Mińsku, w czasopiśmie kilkukrotnie pojawiały się m.in. nawiązania do postaci Marii „Maszy” Bruskiny ${ }^{14}$. Choć egzekucja członkini mińskiego ruchu oporu wykonana została jeszcze w 1941 r., to jednak w opinii autorów artykułów jej postać uosabiała żydowski i sowiecki sprzeciw wobec hitlerowskich okupantów. Kwestia ta zostanie jeszcze rozwinięta w dalszej części niniejszego artykułu. Ponieważ na rok 2015 przypadała siedemdziesiąta rocznica zakończenia II wojny światowej, publikacje były bardziej zróżnicowane. Niemniej jednak w dalszym ciągu przewagę stanowiły artykuły na temat kobiet walczących w oddziałach partyzanckich ${ }^{15}$.

\section{Żydówki w Armii Czerwonej}

Jak zostało to już zasygnalizowane, redakcja wydania internetowego czasopisma ewidentnie starała się podkreślić wkład kobiet żydowskich $\mathrm{w}$ walkę z niemieckim okupantem. Jednakże forma podejmowanej przez nie walki mogła być różnorodna i zależna od wielu czynników bądź też

${ }_{14}$ Por. np. w roku 2008: Izwiestnaja „nieizwiestnaja”, „Jewriejskij Mir” (31 lipca 2008), https://evreimir.com/22468/ [dostęp: 12 kwietnia 2021]; w roku 2018: Dawid Fabrikant, Nie pomiani jewrieja imia kak gieroja... Jeszcze raz o Masze Bruskinoj i zastariełom sowietskom antisiemitizmie, „Jewriejskij Mir” (14 listopada 2018), https://evreimir.com/154001/ne-pomyani-evreya-imya-kak-geroya-eshhe-raz-o-mashe-bruskinoj-i-zastarelom-sovetskom-antisemitizme/ [dostęp: 14 kwietnia 2021].

${ }^{15}$ Mark Sztejnberg, „Oj, Dnipro, Dnipro, ty szyrok, mogucz, nad toboj letiat żurawli”. K 70-j godowszczinie Pobiedy, [część 1], „Jewriejskij Mir” (30 kwietnia 2015), https://evreimir.com/99491/oj-dnipro-dnipro-ty-shirok-moguch-nad-t/; [część 2], tamże (8 maja 2015), https://evreimir.com/99717/oj-dnipro-dnipro-ty-shirok-moguch-nad-t-2/ [dostęp: 14 kwietnia 2021]. 
nawet zbiegów okoliczności. Dotyczy to zwłaszcza Żydówek służących w oddziałach Armii Czerwonej. To zróżnicowanie pod względem rodzaju pełnionej przez nie służby podczas II wojny światowej sprawia, że piszący o nich publicyści mogą w dowolny sposób kształtować pamięć o nich. Zależnie od doboru poruszanego problemu czy przedstawianych postaci mają oni możliwość ukazywania sowieckich kobiet żydowskich jako bohaterskich żołnierek, sanitariuszek lub łączniczek. Przed przystąpieniem do analizy tekstów należy w tym kontekście się przekonać, jak wyglądają statystyki dotyczące form służby pełnionej przez Żydówki. Dane na ten temat przedstawił Aron Szniejer (Shneyer) - zob. tabela 1.

Tabela 1. Żydówki w poszczególnych formacjach wojsk Armii Czerwonej w okresie II wojny światowej (w przeliczeniu na procenty)

\begin{tabular}{|c|c|}
\hline Rodzaj formacji & $\begin{array}{c}\text { Odsetek Żydówek pełniących służbę } \\
\text { w danej formacji [\%] }\end{array}$ \\
\hline Wojska lądowe & 44 \\
\hline Służby medyczne & 29 \\
\hline Łączność & 11 \\
\hline Obrona przeciwlotnicza & 10 \\
\hline Lotnictwo & 6 \\
\hline
\end{tabular}

Źródło: Szniejer, Plen...

Na podstawie danych zawartych w tabeli 1 można stwierdzić, iż zdecydowana większość Żydówek sowieckich (ok. 60\%) służyła w formacjach, które brały regularny udział w walkach z przeciwnikiem. Oczywiście nie wszystkie te kobiety uczestniczyły w działaniach zbrojnych, jednakże zakładając, iż w Armii Czerwonej służyło - jak wspomniano na początku - ok. 20 tys. Żydówek, należy przyjąć, że w bezpośrednią walkę z okupantem zaangażowanych mogło być nawet 12 tys. czerwonoarmistek pochodzenia żydowskiego. To z kolei niszczy utrwalony w kulturze obraz kobiety na froncie jako sanitariuszki. O tym, iż jest on dość mocno utrwalony w pamięci dawnych Żydów sowieckich, świadczą dane przedstawione w tabeli 2.

Co prawda, w tym przypadku materiał badawczy jest dość ograniczony, składa się bowiem jedynie z siedmiu artykułów, które związane są ze służbą kobiet żydowskich w Armii Czerwonej podczas wojny. Przeprowadzona analiza wskazuje jednak na kilka istotnych kwestii. Przede wszystkim na - zasygnalizowany już - utrwalony w świadomości rosyjskojęzycznych 
Żydów wizerunek kobiet na froncie jako sanitariuszek i pracowniczek medycznych. Pogląd ten zdaje się w dalszym ciągu przeważać zarówno w gronie dziennikarzy, jak i zapewne też czytelników. Niemniej jednak w opublikowanych artykułach mimo wszystko zauważalna jest swoista równowaga narracji względem Żydówek. Choć teoretycznie najwięcej publikacji prezentuje sylwetki tych czerwonoarmistek, które służyły podczas wojny jako personel medyczny, to jednak różnica między tymi przedstawieniami a pozostałymi materiałami dziennikarskimi jest minimalna. Stąd można wnioskować, iż pomimo wciąż obecnych w tejże społeczności stereotypów wywodzący się z niej publicyści nieustannie podejmują działania na rzecz ukazania pełnego obrazu dokonań Żydówek na froncie wschodnim w latach 1941-1945.

Tabela 2. Żydówki w poszczególnych formacjach wojsk Armii Czerwonej w okresie II wojny światowej w artykułach wydania internetowego czasopisma „Jewriejskij Mir" $(n=7)$

\begin{tabular}{|c|c|}
\hline Rodzaj formacji & $\begin{array}{c}\text { Liczba artykułów na temat } \\
\text { kobiet żydowskich w danej formacji }\end{array}$ \\
\hline Służby medyczne & 3 \\
\hline Wojska lądowe & 2 \\
\hline Brak określenia konkretnej formacji & 2 \\
\hline Ogółem & 7 \\
\hline
\end{tabular}

Źródło: badania własne na podstawie artykułów zamieszczonych na stronie internetowej czasopisma $\mathrm{z}$ lat 2003-2020.

Niezależnie jednak od tych starań widoczne jest dość ogólne podejście autorów tekstów do poruszanego przez nich problemu. W latach 2003-2020 aż dwukrotnie bowiem wspomnieli o kobietach na froncie, nie poruszając przy tym formy oraz miejsca ich służby. Jako przykład posłużyć może publikacja Jurija Kramera z 2018 r. poświęcona życiu sowieckiej i rosyjskiej dysydentki Jeleny Bonner ${ }^{16}$. W artykule zamieszczono jej zdjęcie w mundurze z 1945 r., sygnalizując czytelnikowi, iż brała udział w działaniach II wojny światowej ${ }^{17}$. Jednakże z samej lektury tekstu nie jest on

${ }^{16}$ Jurij Kramer, Każdyj wybirajet dla siebia. 95 let nazad rodiłas’ Jelena Bonner, „Jewriejskij Mir" (28 lutego 2018), https://evreimir.com/143112/kazhdyj-vybiraet-dlya-sebya-95-let-nazad-rodilas-elena-bonner/ [dostęp: 15 kwietnia 2021]. Tekst ten ukazał się oryginalnie na portalu internetowym Isrageo, co wskazuje na wyraźną współpracę portalu z wydaniem internetowym czasopisma „Jewriejskij Mir”.

17 Por. tamże. 
w stanie zapoznać się bliżej z jej aktywnością na froncie. O służbie Bonner jako pielęgniarki i jej przebiegu dowiedzieć się może dopiero po przeprowadzeniu własnej, indywidualnej kwerendy informacji. Możliwe jednak, iż pomijanie przez autorów pewnych szczegółów o niektórych postaciach wynika nie tyle $\mathrm{z}$ ich podejścia do kwestii udziału kobiet w walkach, ile z przekonania, że pewne zagadnienia związane z podejmowaną przez nich problematyką funkcjonują już w podświadomości czytelników. Dlatego też na przykład zdjęcie Jeleny Bonner w mundurze z końcowego okresu wojny było dla nich wystarczającą informacją o tym, czym zajmowała się ona w jej trakcie. W rezultacie szersze wyjaśnienia nie były konieczne, aby zrozumieć wynikający z treści przekaz.

Lektura badanych publikacji jasno pokazuje, że główną osią przekazu wydania internetowego czasopisma „Jewriejskij Mir” w kontekście jego narracji historycznej jest udowodnienie wojennego bohaterstwa narodu żydowskiego. Przeciwstawia się więc ona forsowanej przez władze sowieckie tezie, jakoby Żydzi mieli być słabymi żołnierzami ${ }^{18}$. Nie może więc dziwić czytelnika spora liczba odwołań w tekstach do poświęcenia ogółu ludności żydowskiej - niezależnie od płci czy wieku jej przedstawicieli na froncie. Doskonale można to zobrazować na przykładzie fragmentu artykułu Marka Sztejnberga z 2018 r. o wymownym tytule Żydzi na frontach wielkiej wojny ojczyźnianej ${ }^{19}$ :

Innymi słowy, co piąty Żyd służył w wojsku w okresie wojny, wliczając wszystkich mężczyzn i kobiety, dzieci i starców. A jeśli porównamy skalę ich uczestnictwa w walce zbrojnej z ogólnym wskaźnikiem, to nie będzie on wcale gorszy. W rezultacie Żydzi w Związku Sowieckim wykonywali swój obowiązek wojskowy w latach wojny z nie mniejszym heroizmem niż reszta populacji $1^{20}$.

Przytoczone powyżej słowa nie tylko podkreślają narodowy solidaryzm Żydów w obliczu zagrożenia ojczyzny podczas działań wojennych,

${ }^{18}$ Wkład Żydów w walkę z okupantem marginalizowano jeszcze w trakcie działań wojennych, co zresztą widoczne było już niemalże bezpośrednio po inwazji III Rzeszy i jej sojuszników na państwo sowieckie, kiedy to w wydanej w 1942 r. publikacji Stalina na temat konieczności obrony ojczyzny zabrakło jakichkolwiek słów w kierunku narodu żydowskiego. Zob. Iosif Stalin, O Wielikoj Otieczestwiennoj wojnie Sowietskogo Sojuza, Pienza 1942.

${ }_{19}$ Mark Sztejnberg, Jewriei na frontach Wielikoj Otieczestwiennoj, „Jewriejskij Mir” (2 maja 2018), https://evreimir.com/144961/evrei-na-frontah-velikoj-otechestvennoj/ [dostęp: 15 kwietnia 2021]. Publikacja oparta została na jednej z wydanych przez Sztejnberga książek. Por. tenże, Jewriejskij szczit SSSR: Oczerki wojennoj istorii jewriejskogo naroda (1941-1991 gg.), Nju Jork 2011.

${ }^{20}$ Sztejnberg, Jewriei na frontach... Wszystkie cytaty z języka rosyjskiego i angielskiego tłumaczył autor artykułu. 
ale też pośrednio wskazują na rolę kobiet i innych grup pochodzenia żydowskiego, takich jak ludzie starsi bądź dzieci. Osoby te, uczestnicząc w walkach na froncie wschodnim, przełamywały stereotypy i uprzedzenia ówczesnego społeczeństwa. W takim wypadku wszystkie walczące z okupantem Żydówki ukazane są nie tylko jako bohaterki wojenne, lecz również jako patriotki, które na nowo zdefiniowały znaczenie kobiecości w społeczeństwie sowieckim. Zauważalne jest to m.in. na przykładzie pilotki pochodzenia żydowskiego Poliny Gelman, a także partyzantki Nadieżdy Wołkowej. Obydwie te kobiety, pomimo odmiennych form i warunków walki, wymieniono w jednym z artykułów przedstawiających sylwetki Żydów wyróżnionych tytułami Bohatera Związku Sowieckiego bądź też Bohatera Federacji Rosyjskiej ${ }^{21}$.

Należy zaznaczyć, iż nawet dobrowolne wstąpienie przez kobietę do Armii Czerwonej nie musiało się wiązać z wysłaniem jej bezpośrednio na front. Niekiedy przydział, jaki otrzymywała, mógł być dla niej źródłem rozczarowań. Z czasem jednak - pod wpływem wydarzeń - te rozczarowania przeradzały się w całkowitą akceptację zastanych warunków. Przykładem mogą tu być losy Sarry Kacowej, która w 2005 r. udzieliła wywiadu jednemu z publicystów czasopisma „Jewriejskij Mir”22. Swoje początki w sowieckiej armii wspominała następująco:

Kiedy wybuchła wojna, wraz z matką zostałam ewakuowana do Kustanaju. Wysłano nas do kołchozów, gdzie dostaliśmy pół funta razowego chleba. Na front dostałam się z Czelabińska. Nasza grupa dziewcząt-ochotniczek została wysłana do Czelabińska, aby uczestniczyć w kursach dla kierowców i telegrafistek. Uczyłyśmy się przez trzy miesiące, a potem od razu ruszyłyśmy na front. Nie mogłam dostać [nogami] do pedałów. Mama widziała, jak źle prowadzę samochód, i prawie się rozpłakała. W końcu kursy obejmowały tylko 10 godzin praktycznej jazdy. Mimo wszystko wysłano nas na front. Tam dostawałyśmy po kawałku suchara i odrobinie cukru. Uważałyśmy, że jadłyśmy bardzo dobrze w porównaniu z pozostałymi ${ }^{23}$.

${ }^{21}$ Wspomnim wsiech poimienno, „Jewriejskij Mir” (21 czerwca 2006), http://evreimir. com/10310/ [dostęp: 15 kwietnia 2021]. Na liście znalazła się także inna Żydówka, Lona Cohen, która otrzymała tytuł Bohatera Federacji Rosyjskiej. Została ona jednak pominięta w niniejszych rozważaniach, ponieważ w czasie wojny była szpiegiem w Stanach Zjednoczonych, a zatem nie brała udziału w bezpośrednich walkach na froncie. Pełna lista dostępna jest w: Sztejnberg, Jewriejskij szczit SSSR..., s. 370-374.

${ }^{22}$ Sarra Kacowa, Mama, miłaja mama, [wywiad przeprowadzony przez redakcję czasopisma], „Jewriejskij Mir” (9 marca 2005), https://evreimir.com/5846/ [dostęp: 15 kwietnia 2021].

${ }^{23}$ Tamże. 
Zarówno powyższe słowa, jak i inne artykuły poświęcone Żydówkom na froncie wschodnim eksponują nie tylko ich determinację oraz siłę, lecz także umiejętność przystosowywania się do trudnych warunków wojennych. Sama Kacowa w czasie swej służby zajmowała się ochroną lotnisk oraz transportem amunicji, a w momencie kapitulacji III Rzeszy stacjonowała na terenie Czechosłowacji ${ }^{24}$. Niemniej jednak doświadczenia walk z okupantem kształtowały osobowość również i innych kobiet żydowskich, co ukazali w swych artykułach dziennikarze badanego czasopisma. Gienia Pierietiat'ko do momentu ataku Niemiec na ZSRS 22 czerwca $1941 \mathrm{r}$. uprawiała strzelectwo sportowe w Odessie, jednocześnie kończąc też szkolenie wojskowe ${ }^{25}$. Kiedy znalazła się na froncie, wykorzystała swój talent strzelecki w walce, stając się jedną z najskuteczniejszych sowieckich snajperek podczas II wojny światowej ${ }^{26}$. Co istotne, w artykule, w którym pojawia się nazwisko Pierietiat'ko, wymienieni są również inni sportowcy pochodzenia żydowskiego oraz ich działalność okresu wojennego. Autor nie ograniczył się przy tym jedynie do osób mieszkających w czasie wojny w państwie sowieckim, ale wspomina też o losach tych, którzy przebywali wówczas na terenie innych okupowanych krajów europejskich. W rezultacie zestawia historie m.in. walczących na froncie wschodnim Żydówek, takich jak Pierietiat'ko, z ofiarami Holokaustu, wśród których wymienia na przykład cztery holenderskie gimnastyczki uczestniczące w igrzyskach olimpijskich w 1928 r. To sprawia, że żydowscy żołnierze Armii Czerwonej, w tym również Żydówki, stają się w narracji czasopisma bohaterami walczącymi o przetrwanie całego narodu.

\section{Żydówki w ruchu oporu}

Prezentowany przez wydanie internetowe czasopisma „Jewriejskij Mir” obraz Żydówek w ruchu partyzanckim i konspiracyjnym nie różni się zasadniczo pod względem swej funkcji narracyjnej od nakreślonego przez redakcję portretu czerwonoarmistek pochodzenia żydowskiego. W obydwu przypadkach chodzi bowiem przede wszystkim o podkreślenie wcześniej

${ }^{24}$ Jak wspomniano podczas wywiadu, to właśnie tam miał ją „zastać Dzień Zwycięstwa”. Por. tamże.

${ }^{25}$ Pamiatju nado dorożyt', „Jewriejskij Mir” (12 maja 2005), https://evreimir.com/6439/ [dostęp: 16 kwietnia 2021].

${ }^{26} \mathrm{~W}$ czasie wojny udało jej się zabić z broni snajperskiej 148 przeciwników. Zob. Zvi Gitelman, A Century of Ambivalence: The Jews of Russia and the Soviet Union, 1881 to the Present, Bloomington-Indianapolis 2001, s. 135. 
wspomnianych zasług, determinacji i odwagi tych kobiet w czasie walki z okupantem. Ze względu jednak na specyfikę warunków działalności tych pierwszych występuje między nimi kilka istotnych różnic. Przede wszystkim w przedstawionych przez autorów sylwetkach partyzantek żydowskich jest zdecydowanie więcej dramatyzmu w sferze narracyjnej. Wynika to $\mathrm{z}$ faktu, iż miejscem ich działalności nie było pole bitwy w tradycyjnym rozumieniu tego słowa, lecz m.in. tereny gett lub lasy. Co więcej, wiele z partyzantek żydowskich ukazanych w badanych publikacjach - w odróżnieniu od Żydówek walczących w Armii Czerwonej - nie odbyło nawet podstawowego przeszkolenia. Pomimo to okazywały się one później na przykład doskonałymi sabotażystkami czy też przewodniczkami dla miejscowych ruchów oporu ${ }^{27}$.

O ile w przypadku żydowskich czerwonoarmistek możliwe było przyjęcie kryteriów, które pozwalały na jakieś ujęcie statystyczne poświęconych im artykułów i wzmianek, o tyle w przypadku partyzantek takich możliwości nie ma, ponieważ informacje na ich temat pojawiają się w publikacjach o różnorodnej tematyce. Często ograniczają się one wręcz jedynie do przywołania tylko imion i nazwisk wybranych kobiet ${ }^{28}$. Przeglądając te artykuły, można jednak zauważyć, iż w zdecydowanej większości wiążą się one z kwestią działalności partyzanckiej na obszarze okupowanej Białorusi, a także ze sprawą kontaktów miejscowych partyzantów z ruchem konspiracyjnym w mińskim getcie. Nie może to jednak specjalnie dziwić, biorąc pod uwagę skalę współpracy między przebywającą tam ludnością żydowską a lokalnym ruchem oporu ${ }^{29}$. Jeden z poruszających ten problem tekstów, autorstwa Dawida Melcera, zawiera ponad trzydzieści krótkich biogramów Żydówek, które odpowiadały zarówno za tę współpracę, jak i za rozwój ruchu konspiracyjnego na terenie getta ${ }^{30}$. Co ciekawe, został on opatrzony słowami białoruskiej pisarki i noblistki Swiatłany Aleksijewicz:

${ }^{27}$ Por. np. Tragiedija i gieroizm, „Jewriejskij Mir” (15 września 2003), https://evreimir. com/54/ [dostęp: 16 kwietnia 2021]; Dawid Melcer, Żenszcziny Minskogo gietto, ili Gieroini antinacystskogo soprotiwlenija, „Jewriejskij Mir” (3 marca 2016), https://evreimir. com/116201/zhenshhiny-minskogo-getto-ili-geroini-antinatsistskogo-soprotivleniya/ [dostęp: 16 kwietnia 2021].

${ }^{28}$ Zob. np.: Ja goworiu s wami iz Oswiencyma..., „Jewriejskij Mir” (24 grudnia 2008), https://evreimir.com/23472/ [dostęp: 16 kwietnia 2021].

${ }^{29}$ Smolar, The Minsk Ghetto... Smolar wspomina również, że w pewnym momencie celem działalności żydowskich partyzantów było wyprowadzenie z getta jak największej liczby osób. W rezultacie od jesieni 1942 do stycznia 1943 r. „udało się wyprowadzić tak wielu Żydów, że konieczne było sformowanie kolejnych oddziałów”. Zob. tamże, s. 115.

${ }^{30}$ Melcer, Żenszcziny Minskogo gietto... 
Jestem absolutnie pewna, że takich dziewczyn jak dziewczyny okresu wojny roku 1941 więcej już nigdy nie będzie. Kochałam bezgranicznie te dziewczyny ${ }^{31}$.

Choć Aleksijewicz, wypowiadając te słowa, miała na myśli wszystkie kobiety sowieckie biorace udział w działaniach wojennych, to ich przytoczenie przez Melcera sprawia, iż zyskują zupełnie nowy wymiar oraz znaczenie. Słowa te sygnalizują bowiem czytelnikom swoistą wyjątkowość oporu Żydówek sowieckich wobec okupantów. Mogą też wskazywać na ich niepowtarzalność oraz fakt, iż poprzez swoje czyny zasłużyły na głębsze uczucie ze strony całej społeczności, o czym świadczy przytoczone zdanie. $\mathrm{Z}$ punktu widzenia całej redakcji czasopisma, a także głoszonej przez nią narracji, wypowiedź ta może się stać apelem do czytelników, aby ci zapamiętali opisywane w tekście czyny jako wyraz miłości tych kobiet do całego narodu żydowskiego. Doszukując się kontekstów historycznych, można zauważyć, iż współczesna gloryfikacja działających w konspiracji Żydówek sowieckich stanowi niejako powrót do tradycji żydowskiej społeczności ZSRS z okresu II wojny światowej, mianowicie otaczania kultem tych Żydów, którzy oddali życie w walce z okupantem.

Doskonałym przykładem tego zjawiska są losy wspomnianej już w niniejszych rozważaniach Marii Bruskiny. Hersz Smolar stwierdził w swej książce, że „opowiadając historię Maszy kolejnym młodym ludziom w getcie, udało się na jego terenie stworzyć grupy oporu"32. Możliwe więc, że wszystkie artykuły wspominające o jej działalności nakierowane są właśnie na przywrócenie tego entuzjazmu następnym pokoleniom. Przy czym zamierzonym efektem nie jest motywacja do walki, lecz do czynnego kultywowania pamięci o żydowskich bohaterach i bohaterkach, wśród których Bruskina zajmuje - według wspominających o niej publicystów - miejsce szczególne. Przypadek ten jest zresztą dość istotny z perspektywy całej społeczności dawnych Żydów sowieckich i ich potomków. Należy bowiem zaznaczyć, iż z powodu antysemickich nastrojów w państwie sowieckim bardzo długo pomijano postać samej Maszy, a także jej pochodzenie. Dlatego też do chwili obecnej rosyjskojęzyczni publicyści określają ją mianem „znanej nieznanej" (izwiestnaja nieizwiestnaja) ${ }^{33}$. W związku z tym przywracanie

31 Tamże.

${ }^{32}$ Smolar, The Minsk Ghetto..., s. 33.

${ }_{33}$ Zob. np. Władimir Opiendik, Izwiestnaja „nieizwiestnaja”. K 70-letiju podpolszczicy gibieli biełorusskoj Maszy Bruskinoj, „Jewriejskij Mir” (1 listopada 2011), https://evreimir. com/69544/Izvestnaya-neizvestnaya-K-70-letiyu-podp/ [dostęp: 17 kwietnia 2021]; Dawid Melcer, Izwiestnaja opiat’ stała „nieizwiestnoj”, „Jewriejskij Mir” (29 października 2015), https://evreimir.com/108388/izvestnaya-opyat-stala-neizvestnoj/ [dostęp: 17 kwietnia 2021]. 
o niej pamięci kolejnym pokoleniom Żydów jest niejako symbolem triumfu ludności żydowskiej nad komunistyczną cenzurą. Moment jej śmierci przedstawiany jest w wydaniu internetowym czasopisma „Jewriejskij Mir” następująco:

Piękna, dostojna dziewczyna w zielonej sukience i lekkiej bluzce szła ulicą z dumnie uniesioną głową. Swoim wyglądem demonstrowała niezrównaną odwagę i wytrwałość. Na piersi miała tabliczkę z napisami w języku niemieckim i rosyjskim: „Jesteśmy partyzantami, którzy strzelali do wojsk niemieckich”. Kaci powiesili bohaterów podziemia przy wejściu do fabryki drożdży „Krasnaja Zaria”34.

Opis śmierci Bruskiny ma dwa wymiary - rzeczywisty i symboliczny. $\mathrm{Z}$ jednej strony ma on na celu ukazanie czytelnikom okoliczności śmierci konspiratorki, która poświęciła swe życie, aby pomagać rannym czerwonoarmistom. Jednakże z drugiej jest też próbą zerwania z obrazem kobiety żydowskiej jako bezbronnej ofiary nazistowskiego terroru. W obliczu śmierci Masza zachowuje spokój, gdyż wierzy, że umrze w słusznej sprawie.

Cechą wspólną znacznej części tekstów poświęconych Żydówkom-konspiratorkom jest, wspomniana wcześniej, wyraźna narracja dramatyczna. Istotną rolę w jej budowaniu odgrywają nie tylko opisy śmierci, lecz także częste podkreślanie młodego wieku wielu z tych kobiet. O tym, w jaki sposób młodość i wynikająca z niej niewinność stawały się bronią sowieckiego ruchu oporu, można się dowiedzieć, czytając w czasopiśmie na przykład o losach piętnastoletniej Ludmiły Zarieckiej. W 1943 r. udało jej się zbiec z mińskiego getta, a następnie dołączyć do oddziału partyzanckiego pod dowództwem Dawida Kojmacha. Podczas jednej z akcji Zariecka została jednak zatrzymana przez Niemców i doprowadzona do miejscowej siedziby Gestapo. Moment jej przesłuchania opisany został następująco:

W trakcie przesłuchania przez funkcjonariuszy Gestapo dziewczyna tak dramatycznie opowiedziała wcześniej przygotowaną historię o tym, że jedzie do miasta, aby wymienić żywność na lekarstwa dla swojej chorej babci, że gestapowcy jej uwierzyli ${ }^{35}$.

Publicyści związani z wydaniem internetowym czasopisma „Jewriejskij Mir” wspominają nie tylko o Żydówkach zaangażowanych w działalność ruchu oporu na Białorusi, ale też i tych, które działały na terenie

\footnotetext{
${ }^{34}$ Tamże.

${ }^{35}$ Melcer, Żenszcziny Minskogo gietto...
} 
okupowanej Ukrainy. Doskonałym tego przykładem jest Tatiana Markus ${ }^{36}$. Analizując jej życiorys opublikowany na stronie tygodnika w 2007 r., zauważyć można sporo podobieństw w opisie jej ówczesnego wyglądu do tego, który pojawił się w przytoczonym wcześniej fragmencie poświęconym śmierci Maszy Bruskiny. W obydwu bowiem przypadkach autorzy zwrócili szczególną uwagę na urodę wspomnianych kobiet. Markus opisana została jako „piękna dziewczyna o wyrazistych oczach, cudownych włosach i delikatnym rumieńcu" ${ }^{37}$. Jednakże ten barwny opis stanowi wyłącznie wstęp do rozważań nad zasługami wojennymi konspiratorki pochodzenia żydowskiego. Rozważania te zawierają elementy narracji, które z jednej strony świadczą o wyraźnym patriotyzmie konspiratorki, a z drugiej też o jej odwadze, niekiedy wręcz graniczącej z brawurą.

W dniu pierwszej faszystowskiej parady na Chreszczatyku ${ }^{38}$ ona [Markus - dop. K. P.] i jej dowódca Gieorgij Lewicki udali się na pierwszą misję bojową. Z balkonu drugiego piętra ogromnego domu naprzeciw poczty rzucili w kolumny maszerujących Niemców bukiet astrów... z granatem. W rezultacie zginęło wielu faszystów ${ }^{39}$.

Powyższy fragment oraz inne przytoczone przez autora dokonania Markus ukazują ją jako postać odważną, a ponadto niezwykle kreatywną w swych działaniach. Zestawiając sposób, w jaki została ona przedstawiona przez redakcję, z przykładami innych wspomnianych wcześniej kobiet, takich jak Bruskina czy Zariecka, zauważyć można istotną specyfikę obrazu Żydówek w sowieckim ruchu oporu. Choć - podobnie jak w przypadku czerwonoarmistek - starania autorów koncentrują się na pokazaniu ich bohaterstwa i determinacji, to jednak czytelnik dostrzec może wyraźną nieszablonowość tych kobiet. O ile Żydówki w Armii Czerwonej ukazywane są jako wyzwolicielki, które pomimo licznych przeciwności dążyły do pokonania okupanta, o tyle sowieckie konspiratorki i partyzantki pochodzenia żydowskiego uosabiają w narracji dziennikarzy chęć przetrwania całego narodu w okresie wojny. Jak pokazuje lektura badanych artykułów, nie wahały się one wykorzystywać swojego wyglądu czy sprytu do osiągnięcia zamierzonego celu.

${ }^{36}$ Gieroj ukrainy [sic!] Tatjana Markus, „Jewriejskij Mir” (14 lutego 2007), https://evreimir.com/14407/ [dostęp: 17 kwietnia 2021]. W literaturze Markus określana jest również jako „Tania” - por. np. Arad, In the Shadow of the Red Banner..., s. 243.

37 Tamże.

${ }^{38}$ Główna aleja Kijowa.

${ }^{39}$ Gieroj ukrainy Tatjana Markus... 
Należy jednak przy tym zaznaczyć, iż tenże obraz wydaje się niepełny. Przykłady Bruskiny, Markus czy Zarieckiej dowodzą, co prawda, rzeczywistego bohaterstwa wielu Żydówek w czasie II wojny światowej. Niemniej jednak mogą się one jednocześnie przyczyniać do idealizowania przez czytelników czasopisma zaangażowania kobiet w działalność sowieckiej partyzantki i ruchu oporu. W przytoczonych materiałach dziennikarskich zazwyczaj brakuje wzmianek dotyczących wielu aspektów ich życia wśród partyzantów, m.in. kwestii wykorzystywania seksualnego kobiet przez sowieckich dowódców. Już po wojnie wiele uczestniczek walk partyzanckich wspominało, iż często jedyną szansą na przeżycie było dla nich zostanie kochanką jednego $\mathrm{z}$ oficerów ${ }^{40}$.

Nieuwzględnienie tych wspomnień, podobnie jak i innych traumatycznych relacji czy faktów, w artykułach wydania internetowego czasopisma „Jewriejskij Mir” wynika najprawdopodobniej z co najmniej dwóch powodów. Pierwszym może być przyzwyczajenie znacznej części autorów i czytelników do sowieckiej narracji historycznej idealizującej, a wręcz gloryfikującej, walkę z wrogiem. Ewentualne wzmianki o nadużyciach ze strony sowieckich oficerów mogłyby stać się przedmiotem kontrowersji i podziałów wśród rosyjskojęzycznej społeczności żydowskiej. Wydaje się jednak, że o wiele istotniejszym powodem braku podobnych treści w badanych artykułach jest fakt, iż w chwili ich publikacji żyło jeszcze wiele dawnych działaczek ruchu oporu i partyzantek, a także ich bliskich. Opisanie przez dziennikarzy przypadków dyskryminacji czy też wykorzystywania seksualnego kobiet w oddziałach partyzanckich mogłoby doprowadzić nie tylko do „przymusowej” konfrontacji tych osób z trudnymi wspomnieniami, lecz także naraziłoby je na ewentualne pomówienia bądź domysły ze strony znajomych czy sąsiadów.

\section{Podsumowanie}

W świetle powyższych analiz nie sposób nie zauważyć, iż dyskurs naukowy i publicystyczny na temat roli kobiet żydowskich na froncie wschodnim jest istotnym elementem odzyskiwania przez dawnych Żydów sowieckich

${ }^{40}$ Wspomnienia niektórych z nich zostały zaprezentowane w jednym z filmów dokumentalnych przygotowanych przez Jewish Partisan Educational Foundation - zob. Every Day the Impossible: Jewish Women in the Partisans, Jewish Partisan Educational Foundation, 2006, [w:] Facing History \& Ourselves, https://www.facinghistory.org/resource-library/video/ every-day-impossible-jewish-women-partisans [dostęp: 30 sierpnia 2021]. 
i ich potomków utraconej w przeszłości tożsamości żydowskiej. W procesie tym ważną rolę odgrywają wywodzące się $\mathrm{z}$ tych środowisk media, takie jak czasopismo „Jewriejskij Mir” i jego wydanie internetowe. To właśnie związani z nimi publicyści tworzą właściwą przestrzeń do rozważań nad rolą Żydówek w pokonaniu III Rzeszy. Poprzez prezentowanie konkretnych sylwetek z okazji różnorakich obchodów rocznicowych i innych okoliczności biorą oni aktywny udział w kształtowaniu pamięci i świadomości historycznej rosyjskojęzycznej społeczności żydowskiej. Działalność ta skutkuje ponadto wytworzeniem się w tym środowisku swoistego kanonu bohaterów i bohaterek, w którym istotną rolę odgrywają sowieckie czerwonoarmistki i partyzantki pochodzenia żydowskiego.

Ich przykłady stanowić mają wzór dla kolejnych pokoleń, a jednocześnie też motywację do dalszego odkrywania przez rosyjskojęzycznych Żydów ich dziedzictwa i przeszłości. Co więcej, wspominanie o dokonaniach kobiet żydowskich na froncie wschodnim II wojny światowej może mieć na celu także wzmocnienie więzi społecznych wśród posługującej się językiem rosyjskim ludności żydowskiej. Widać to wyraźnie w momencie przywołania w jednym z artykułów słów Swiatłany Aleksijewicz, w których pisarka wspomniała o swojej miłości do kobiet biorących udział w działaniach wojennych. Choć oryginalnie słowa te odnosiły się do ogółu „dziewczyn okresu wojny" na froncie wschodnim, na skutek odpowiednich zabiegów redakcji stały się zachętą do budowania przez czytelników emocjonalnej więzi z przedstawianymi w artykułach postaciami. W ten sposób podkreślany jest patriotyzm i odwaga Żydówek sowieckich, które podejmując walkę z okupantem, występowały nie tylko w obronie ZSRS, lecz także całej ludności żydowskiej.

Należy nadmienić, iż obraz ten nie jest całkowicie jednolity. Chociaż głównym celem wszystkich publikacji na temat udziału kobiet sowieckich w walkach jest ukazanie ich siły i determinacji, obrazy Żydówek w Armii Czerwonej i w sowieckim ruchu oporu różnią się od siebie. Czerwonoarmistki ukazywane są jako wyzwolicielki, które poprzez swoją służbę walczyły o przetrwanie całego narodu żydowskiego. Natomiast żydowskie konspiratorki i partyzantki na terenach okupowanego państwa sowieckiego uosabiają w przekazie medialnym „duszę” tego narodu - wolę przetrwania oraz pokonania wroga za pomocą wszelkich możliwych środków. Co więcej, posiłkując się przykładami kobiet takich jak skazana na śmierć za pomoc żołnierzom Armii Czerwonej Maria Bruskina, redakcja podejmuje próbę obalenia narracji prezentującej Żydów wyłącznie jako ofiary wojenne. 
Odbiorca zapoznaje się tu bowiem z obrazem Żydówek, które nawet w obliczu śmierci potrafią okazywać odwagę, a także dumę ze swojego pochodzenia.

Przyjęcie przez dziennikarzy takiego sposobu kreowania wizerunku walczących kobiet żydowskich nieuchronnie przyczynia się do idealizacji ich życia i działań w świadomości czytelników czasopisma. Wydaje się jednak, iż podobne zabiegi wynikać mogą w dużej mierze z czynników społecznych i być może stanowią jedynie etap przejściowy w procesie odzyskiwania przez rosyjskojęzycznych Żydów ich własnej tożsamości.

\section{Bibliografia}

\section{1. Źródła opublikowane}

Every Day the Impossible: Jewish Women in the Partisans, Jewish Partisan Educational Foundation, 2006, [w:] Facing History \& Ourselves, https://www.facinghistory. org/resource-library/video/every-day-impossible-jewish-women-partisans [dostęp: 30 sierpnia 2021].

Fabrikant Dawid, Nie pomiani jewrieja imia kak gieroja... Jeszcze raz o Masze Bruskinoj i zastariełom sowietskom antisiemitizmie, „Jewriejskij Mir” (14 listopada 2018), https://evreimir.com/154001/ne-pomyani-evreya-imya-kak-geroya-eshhe-raz-omashe-bruskinoj-i-zastarelom-sovetskom-antisemitizme/ [dostęp: 14 kwietnia 2021].

Gieroj ukrainy Tatjana Markus, „Jewriejskij Mir” (14 lutego 2007), https://evreimir. com/14407/ [dostęp: 17 kwietnia 2021].

Izwiestnaja „nieizwiestnaja”, „Jewriejskij Mir” (31 lipca 2008), https://evreimir. com/22468/ [dostęp: 12 kwietnia 2021].

Ja goworiu s wami iz Oswiencyma..., „Jewriejskij Mir” (24 grudnia 2008), https:// evreimir.com/23472/ [dostęp: 16 kwietnia 2021].

Kacowa Sarra, Mama, milaja mama, [wywiad przeprowadzony przez redakcje czasopisma], „Jewriejskij Mir” (9 marca 2005), https://evre-imir.com/5846/ [dostęp: 15 kwietnia 2021].

Kramer Jurij, Każdyj wybirajet dla siebia. 95 let nazad roditas' Jelena Bonner, „Jewriejskij Mir” (28 lutego 2018), https://evreimir.com/143112/kazhdyjvybiraet-dlya-sebya-95-let-nazad-rodilas-elena-bonner/ [dostęp: 15 kwietnia 2021].

Melcer Dawid, Izwiestnaja opiat' stała „nieizwiestnoj”, „Jewriejskij Mir” (29 października 2015), https://evreimir.com/108388/izvestnaya-opyat-stalaneizvestnoj/ [dostęp: 17 kwietnia 2021].

Melcer Dawid, Żenszcziny Minskogo gietto, ili Gieroini antinacystskogo soprotiwlenija, „Jewriejskij Mir” (3 marca 2016), https://evreimir.com/116201/zhenshhinyminskogo-getto-ili-geroini-antinatsistskogo-soprotivleniya/ [dostęp: 16 kwietnia 2021]. 
O nas, „Jewriejskij Mir” (b.d.), https://evreimir.com/o-nas/ [dostęp: 11 kwietnia 2021].

Oni byli pierwymi, „Jewriejskij Mir” (9 marca 2005), https://evreimir.com/5845/ [dostęp: 12 kwietnia 2021].

Opiendik Władimir, Izwiestnaja „nieizwiestnaja”. K 70-letiju podpolszczicy gibieli biełorusskoj Maszy Bruskinoj, „Jewriejskij Mir” (1 listopada 2011), https:// evreimir.com/69544/Izvestnaya-neizvestnaya-K-70-letiyu-podp/ [dostęp: 17 kwietnia 2021].

Pamiatju nado dorożyt', „Jewriejskij Mir” (12 maja 2005), https://evreimir.com/6439/ [dostęp: 16 kwietnia 2021].

Sztejnberg Mark, Jewriei na frontach Wielikoj Otieczestwiennoj, „Jewriejskij Mir" (2 maja 2018), https://evreimir.com/144961/evrei-na-frontah-velikojotechestvennoj/ [dostęp: 15 kwietnia 2021].

Sztejnberg Mark, „Oj, Dnipro, Dnipro, ty szyrok, mogucz, nad toboj letiat żurawli”. K 70-j godowszczinie Pobiedy, [część 1], „Jewriejskij Mir” (30 kwietnia 2015), https://evreimir.com/99491/oj-dnipro-dnipro-ty-shirok-moguch-nad-t/; [część 2], tamże (8 maja 2015), https://evreimir.com/99717/oj-dnipro-dniproty-shirok-moguch-nad-t-2/ [dostęp: 14 kwietnia 2021].

Tragiedija i gieroizm, „Jewriejskij Mir” (15 września 2003), https://evreimir.com/54/ [dostęp: 16 kwietnia 2021].

Wspomnim wsiech poimienno, „Jewriejskij Mir” (21 czerwca 2006), http://evreimir. com/10310/ [dostęp: 15 kwietnia 2021].

\section{Opracowania}

Ainsztein Reuben, Jewish Resistance in Nazi-Occupied Eastern Europe: With a Historical Survey of the Jew as Fighter and Soldier in the Diaspora, New York 1974. Altshuler Mordechai, Jewish Combatants of the Red Army Confront the Holocaust, [w:] Soviet Jews in World War II: Fighting, Witnessing, Remembering, red. Harriet Murav, Gennady Estraikh, Boston 2014.

Arad Yitzhak, In the Shadow of the Red Banner: Soviet Jews in the War Against Nazi Germany, Jerusalem 2010.

Budnicki Oleg, Mużcziny i żenszcziny w Krasnoj Armii (1941-1945), „Cahiers du Monde Russe" 52 (2011), nr 2-3.

Gitelman Zvi, A Century of Ambivalence: The Jews of Russia and the Soviet Union, 1881 to the Present, Bloomington-Indianapolis 2001.

Krylova Anna, Radzieckie kobiety w walce. Historia przemocy na froncie wschodnim, tłum. Kamil Janicki, Zakrzewo 2012.

Markwick Roger D., Cardona Euridice C., Soviet Women on the Frontline in the Second World War, New York 2012.

Mużykowska Wieronika, Amirow Walerij, Tragiedija Chołokosta i zarubieżnyje russkojazycznyje jewriejskije SMI: osobiennosti sowriemiennogo osmyslenija, „Politiczeskaja Lingwistika” (2018), nr 1.

Pospiełow Piotr, Istorija Wielikoj Otieczestwiennoj Wojny Sowietskogo Sojuza 19411945 gg., t. 1-6, Moskwa 1960-1965. 
Smolar Hersh, The Minsk Ghetto: Soviet-Jewish Partisans Against the Nazis, New York 1989.

Stalin Iosif, O Wielikoj Otieczestwiennoj wojnie Sowietskogo Sojuza, Pienza 1942. Szniejer (Shneyer) Aron, Plen: Sowietskije wojennoplennyje w Giermanii 1941-1945, Moskwa-Ijerusalim 2005, w: Jewniverse - Yiddish Shteytl, http://www.jewniverse.ru/RED/Shneyer/index.htm [dostęp: 11 kwietnia 2021].

Sztejnberg Mark, Jewriejskij szczit SSSR: Oczerki wojennoj istorii jewriejskogo naroda (1941-1991 gg.), Nju Jork 2011.

Tolts Mark, Demography of the Contemporary Russian-Speaking Jewish Diaspora, [w:] The New Jewish Diaspora: Russian-Speaking Immigrants in the United States, Israel, and Germany, red. Zvi Gitelman, New Brunswick 2016.

Krystian Propola Uniwersytet Rzeszowski k.propola@gmail.com 